\title{
The influence of methods of obtaining planting material on the formation of productivity in blue honeysuckle plantations
}

\author{
D.M. Bryksin* \\ FSBSI " I.V. Michurin Federal Scientific Centre", 393774, Michurinsk, Russia
}

\begin{abstract}
Blue honeysuckle has successfully become one of the industrial berry crops of the XXI century. The area of blue honeysuckle plantations in Russia exceeds 500 hectares. More than 210 varieties of blue honeysuckle of Russian and foreign breeding were collected at the experimental sites of the SPC "Agropishcheprom". As a result of the breeding work carried out, the Michurinskoye Divo blue honeysuckle variety, which has a set of requirements for industrial varieties, was transferred to the state variety testing. The main problem when laying commercial blue honeysuckle plantations is the lack of high-quality planting material of new varieties. Planting material of blue honeysuckle, on an industrial scale, is obtained in several ways: hardwood cuttings, soft wood cuttings and in vitro method. The work presents the results of studying the influence of planting material obtained by various methods and used when establishing plantations for the growth, development and formation of productivity of the Michurinskoe Divo blue honeysuckle variety. The positive influence of the in vitro propagation method for the qualitative indicators of the root system of the obtained seedlings, growth activity, potential productivity and yield in the production plantings of the Michurinskoe Divo blue honeysuckle variety, in comparison with seedlings obtained by other reproduction methods, was revealed.
\end{abstract}

\section{Introduction}

The annually increasing demand for blue honeysuckle planting material is justified by the growth of the area of industrial plots of the crop. To date, more than 500 hectares of industrial blue honeysuckle plantations have been planted in Russia. The main part of the plantings was laid over the last 5 years. The leading producers of blue honeysuckle fruits are LLC "Severny Sad", Bakcharsky OPSS, LLC "Rassvet", PFE "Shuiskiye yagody", PFE "Divny Sad" and other farms. From among the amateur crops, which blue honeysuckle was until 2010, the crop was successfully introduced into industrial gardens. The demand for fruits has increased, new processed products have appeared. In 2020, large farms for the first time entered chain supermarkets with blue honeysuckle fruits, their sales volume amounted to 20 tons [1]. Marketing research has shown that blue honeysuckle is primarily valued as a fresh product, which is explained by the high biochemical and vitamin value of

* Corresponding author: lonicera.konf@mail.ru 
the fruit. According to many researchers, they contain a whole complex of biologically active substances and vitamins, have a high therapeutic and dietary value [2-4]. Despite this, many new processed products are appearing in chain supermarkets and online stores, conquering the Russian market.

The breeding work on blue honeysuckle in Russia is developing rapidly. In 2003, E.P. Kuminov [5] outlined the selection requirements for modern varieties of blue honeysuckle, but now they need to be adjusted. The requirements of chain stores to extend the delivery time of fresh fruits imply the introduction of new varieties and technological solutions. Successful breeding work on the creation of late-maturing samples conducted by Canadian researchers allowed to identify such varieties as Tundra, Borealis, Indigo Treat, Indigo Jem, Indigo Yum, Honey Bee, Aurora, Boreal Blizzard, Boreal Beauty and Boreal Beast [6] maturing in our zone from June to July [7]. The zoning of the crop cultivation is also one of the solutions to increase the delivery time of fresh fruits. Thus, in the Voronezh region, it is possible to harvest Russian varieties at an earlier term, and industrial cultivation of blue honeysuckle in the Tomsk region contributes to an increase in the maturation period until July. One of the breakthrough solutions to this issue was proposed by academician V.A. Gudkovsky and a group of scientists of the I.V. Michurin Federal Scientific Centre, who have been working on the issues of storing the fruits of modern blue honeysuckle varieties under regulated conditions for more than 15 years [8,9]. Already in 2020, the possibility of increasing the shelf life of fruits of some varieties, according to the technology developed by them, to 50 days has been determined.

With annual increases in the rate of establishing of blue honeysuckle industrial plantations, the selection of industrial assortment and the possibility of acquiring the necessary amount of planting material of modern varieties for a certain growing area are urgent issues. To date, the industrial production of blue honeysuckle planting material in Russia is just being formed. Despite the long-term breeding work with the crop in Russia, which began in 1930 [10], and an extensive list of varieties (more than 110) included in the state register of the Russian Federation in 2020 [11], blue honeysuckle nursery production, which guarantees proper quality, identity of variety and volume, is established only in a few nurseries: Bakcharsky OPSS, NIISS of Siberia [12]. There are also many different nurseries and online stores offering an extensive list of varieties, but the quality of the planting material sold in them is questionable. The main methods of industrial propagation of blue honeysuckle in Russia are propagation by hardwood and soft wood cuttings [13]. The in vitro method allows to obtain a higher-quality healthy planting material of blue honeysuckle on a virus-free basis [14]. This method is the leading one in the production of blue honeysuckle planting material in Europe. In Russia, this method just begins to develop. To date, up to 300 thousand micro-plants of modern blue honeysuckle varieties are grown in the scientific and production laboratory of the SPC "Agropishcheprom" per year, and the new biotechnological complex, planned to be launched in 2023, is aimed at producing 15 million plants. There have been no studies on the influence of methods for obtaining planting material for the growth, development, and formation of blue honeysuckle productivity in Russia. In this regard, the conducted research is relevant.

\section{Material and methods}

The research was carried out from 2016 to 2020 at the experimental site of the department of genetic collections and breeding of fruit and berry crops of the SPC "Agropishcheprom" in 2016, the laboratory of clonal micro-reproduction of the SPC "Agropishcheprom", the department of nursery breeding of the SPC "Agropishcheprom". The objects of research were the blue honeysuckle variety Michurinskoe Divo, selected by the SPC "Agropishcheprom". When laying the field experiment, planting material obtained in 
various ways was used: propagated by hardwood and soft wood cuttings, as well as by the in vitro method. The experimental samples are placed in a well-lit site. Planting scheme 4.0 $\mathrm{x} 1.0 \mathrm{~m}$. The soil of the site is represented by low-humus chernozem, medium-alkaline, deep medium-loamy. The methodological basis of the work was the "Program and methodology of variety study of fruit, berry and nut crops" [15].

\section{Results and discussion}

The results of the assessment of the root system development of blue honeysuckle planting material obtained by different methods revealed significant differences in the number of roots and their length (Table 1). Thus, the number and length of roots at the age of 4 months was the smallest in seedlings obtained by the method of propagation by hardwood cuttings. The plants obtained by the in vitro method were planted for adaptation in the II decade of May and were 4 months old at the time of registration. This method allowed to achieve the best results in terms of the root system quality, the number of roots was 23 pcs., the length of the roots was $289 \mathrm{~cm}$.

Table 1. Parameters of the root system of the planting material of the blue honeysuckle variety Michurinskoe Divo, obtained by various methods, 2016

\begin{tabular}{|l|c|c|}
\hline $\begin{array}{c}\text { Method of obtaining } \\
\text { planting material }\end{array}$ & $\begin{array}{c}\text { Number of roots, } \\
\text { pcs. }\end{array}$ & $\begin{array}{c}\text { Length of roots, } \\
\text { cm. }\end{array}$ \\
\hline Rooted hardwood cutting & 9 & 108 \\
\hline Rooted soft wood cutting & 14 & 145 \\
\hline In vitro plant & 23 & 289 \\
\hline LSD 05 & 2 & 17 \\
\hline
\end{tabular}

After measurements of the root system, the planting material in the form of rooted hardwood and soft wood cuttings, as well as adapted plants obtained by the in vitro method, was planted in a permanent place in the fall 2016. When planting, the plants were buried 2$3 \mathrm{~cm}$ below the root neck and cut off, leaving 1 internode above the soil level.

Blue honeysuckle shoots are formed from buds on the accretion of the previous year and have a length from 5 to $35 \mathrm{~cm}$. There are also root suckers in blue honeysuckle. They are not numerous; they are formed from dormant buds or on older wood. Their length ranges from 50 to $90 \mathrm{~cm}$ [16]. The indicator of blue honeysuckle growth activity largely determines the size of the next year's harvest [17]. The value of the growth activity indicator varied both in different variants of the experiment and by the years of the study (Table 2). The total length of growth over the years of research, in plants grown using planting material obtained by hardwood cuttings, was the smallest and amounted to 16.0 $\mathrm{m} /$ bush. The use of planting material obtained by in vitro method led to an increase in this indicator by 2.5 times (up to $39.3 \mathrm{~m} / \mathrm{bush}$ ). Moreover, in this version of the experiment, the formation of basal shoots was observed already in the second year (in 2018). The variant with the use of plants obtained by the method of soft wood cuttings also exceeded the variant with hardwood cuttings in growth length by 1.5 times but was significantly inferior to the variant using the in vitro method.

Table 2. Growth activity of the blue honeysuckle variety Michurinskoe divo, depending on the method of obtaining planting material, 2017-2020

\begin{tabular}{|l|c|c|c|c|c|c|}
\hline \multirow{2}{*}{$\begin{array}{c}\text { Method of obtaining planting } \\
\text { material }\end{array}$} & \multicolumn{6}{|c|}{ Length of one-year accretion, m/bush } \\
\cline { 2 - 8 } & 2017 & 2018 & 2019 & 2020 & $\Sigma$ & $\overline{\mathrm{x}}$ \\
\hline Rooted hardwood cutting & 1.2 & 2.2 & 4.1 & 8.5 & 16.0 & 4.0 \\
\hline Rooted soft wood cutting & 1.7 & 2.7 & 6.9 & 12.0 & 23.3 & 5.8 \\
\hline
\end{tabular}




\begin{tabular}{|l|c|c|c|c|c|c|}
\hline In vitro plant & 2.9 & 4.9 & 9.1 & 22.4 & 39.3 & 9.8 \\
\hline LSD 05 & 0.3 & 0.5 & 1.2 & 2.9 & 3.7 & 0.9 \\
\hline
\end{tabular}

The structure and physiology of blue honeysuckle flowers are characteristic of crosspollinated plants, so blue honeysuckle is almost self-fertile. The fruit-settings with natural self-pollination are low. With cross-pollination, it reaches 50-100\%. The blue honeysuckle flowers are quite large, $1-2 \mathrm{~cm}$ long, from pale yellow to greenish. They are collected in biflorous inflorescences - there are two flowers per one fruit-set $[16,17]$.

According to the number of dichasiums on 1 linear meter of annual wood, ambiguous results were obtained. Thus, in 2017 and 2018, in the variant using the planting material obtained by the in vitro method, this indicator was higher in comparison with the other variants presented in the experiment (Table 3). In 2019 and 2020, the indicator of the number of dichasiums in the variants used was within the error range.

The blue honeysuckle fruits are single, on pedicels of $0.5-1.5 \mathrm{~cm}$ long. The shape of the fruit varies by variety and can be oval, round, fusiform, teardrop, etc. There were no significant differences in the used variants of the experiment in the number of fruits per 1 1.m. of the one-year growth was not found.

Table 3. Assessment of potential productivity and its components in the blue honeysuckle variety Michurinskoe divo, depending on the method of obtaining planting material, 2017-2020.

\begin{tabular}{|c|c|c|c|c|c|}
\hline \multicolumn{2}{|c|}{ Indicator / Year } & $\begin{array}{l}\text { Rooted hardwood } \\
\text { cutting }\end{array}$ & $\begin{array}{l}\text { Rooted soft } \\
\text { wood cutting }\end{array}$ & $\begin{array}{l}\text { In vitro } \\
\text { plant }\end{array}$ & LSD 05 \\
\hline \multirow{5}{*}{$\begin{array}{l}\text { Number of } \\
\text { dichasiums, } \\
\text { pcs/l.m. }\end{array}$} & 2017 & 26 & 27 & 31 & 2 \\
\hline & 2018 & 24 & 31 & 35 & 3 \\
\hline & 2019 & 27 & 31 & 32 & 2 \\
\hline & 2020 & 22 & 24 & 24 & 2 \\
\hline & $\overline{\mathrm{x}}$ & 25 & 28 & 31 & 3 \\
\hline \multirow{5}{*}{$\begin{array}{l}\text { Number of fruits, } \\
\text { pcs/l.m. }\end{array}$} & 2017 & 21 & 21 & 22 & 1 \\
\hline & 2018 & 20 & 23 & 24 & 1 \\
\hline & 2019 & 21 & 24 & 23 & 1 \\
\hline & 2020 & 19 & 20 & 20 & 1 \\
\hline & $\bar{x}$ & 20 & 22 & 22 & 1 \\
\hline \multirow{5}{*}{$\begin{array}{l}\text { Average fruit } \\
\text { mass, } g\end{array}$} & 2017 & 1.3 & 1.3 & 1.5 & 0.1 \\
\hline & 2018 & 1.4 & 1.5 & 1.5 & 0.1 \\
\hline & 2019 & 1.5 & 1.6 & 1.6 & 0.1 \\
\hline & 2020 & 1.4 & 1.4 & 1.5 & 0.1 \\
\hline & $\overline{\mathrm{x}}$ & 1.4 & 1.5 & 1.6 & 0.1 \\
\hline \multirow{5}{*}{$\begin{array}{l}\text { Potential } \\
\text { productivity. } \\
\mathrm{kg} / \text { bush }\end{array}$} & 2017 & 0.04 & 0.06 & 0.14 & 0.03 \\
\hline & 2018 & 0.07 & 0.13 & 0.26 & 0.05 \\
\hline & 2019 & 0.17 & 0.34 & 0.46 & 0.09 \\
\hline & 2020 & 0.26 & 0.40 & 0.81 & 0.11 \\
\hline & $\bar{x}$ & 0.14 & 0.23 & 0.42 & 0.09 \\
\hline
\end{tabular}

The use of planting material obtained by different methods did not have a significant impact on the average fruit weight. The weather conditions developed during the formation and ripening of the fruits had a slight impact. In 2019. during the formation and maturation of blue honeysuckle fruits. a higher amount of precipitation was observed at low temperatures compared to 2017. which led to a slight increase in the average fruit weight. A positive correlation was established between the average fruit weight and the amount of 
precipitation during the period of fruit formation and maturation in $2017(\mathrm{r}=0.51) .2018$ $(\mathrm{r}=0.26) .2019(\mathrm{r}=0.63)$ and $2020(\mathrm{r}=0.30)$.

Yield is the most important indicator of the economic value of the variety. It is known that the maximum possible yield depends on the potential characteristics of the variety [18].

Potential productivity is understood as the ability of plants to utilize a certain amount of solar energy and other components (water, oxygen, fertilizer elements) in the form of organic matter under ideal environmental conditions at various stages of organogenesis [19]. The potential of blue honeysuckle is largely determined by the variety growth activity [20].

The extreme indicators of potential productivity in 2017 were $0.04-0.14 \mathrm{~kg} / \mathrm{bush}$. in $2018-0.07-0.26 \mathrm{~kg} / \mathrm{bush}$. in $2019-0.17-0.46 \mathrm{~kg} / \mathrm{bush}$ and in $2020-0.26-0.81 \mathrm{~kg} / \mathrm{bush}$. Moreover, the option using the planting material obtained by the in vitro method had an annual significant superiority in comparison with the option of using hardwood cuttings when laying a plot.

The tasks of modern blue honeysuckle breeding include the creation of early-maturing varieties. Most of the first-generation blue honeysuckle varieties were characterized by low yields and a long period of entry of plants into industrial fruiting. As a rule. these varieties yielded $0.7 \mathrm{~kg}$ per bush only for 6-7 years after the plantation was laid by two-year-old seedlings and this indicator did not exceed $1.5 \mathrm{~kg}$ per bush during the full fruiting period. Already today highly productive varieties have been created with a yield of more than $3 \mathrm{~kg}$ per bush. Nevertheless. the issue of the early fruitfulness of such varieties is largely determined not only by the varietal characteristics. but also by the agrotechnical conditions of establishing and subsequent cultivation of the plantation. As a result of the conducted studies. the variation of the yield indicator was established when using blue honeysuckle planting material of the Michurinskoe Divo variety obtained by different methods of propagation in the laying of fruit-bearing plantings (Table 4).

Table 4. Characteristics of the yield of the blue honeysuckle variety Michurinskoe Divo in connection with the use of planting material obtained by various methods 2017-220.

\begin{tabular}{|l|c|c|c|c|c|c|}
\hline \multirow{2}{*}{$\begin{array}{c}\text { Method of obtaining } \\
\text { planting material }\end{array}$} & \multicolumn{6}{|c|}{ Yield. kg/bush } \\
\cline { 2 - 7 } & 2017 & 2018 & 2019 & 2020 & $\Sigma$ & $\overline{\mathrm{x}}$ \\
\hline Rooted hardwood cutting & 0.03 & 0.06 & 0.12 & 0.22 & 0.43 & 0.11 \\
\hline Rooted soft wood cutting & 0.04 & 0.09 & 0.26 & 0.33 & 0.72 & 0.18 \\
\hline In vitro plant & 0.09 & 0.18 & 0.33 & 0.67 & 1.27 & 0.32 \\
\hline LSD 05 & 0.01 & 0.01 & 0.05 & 0.04 & 0.10 & 0.04 \\
\hline
\end{tabular}

In this way. when using the planting material obtained by the method of hardwood cuttings, the dynamics of yield growth was low and varied over the years from 0.03 to 0.22 $\mathrm{kg} / \mathrm{bush}$. which is explained by the low growth activity of plants. The use of planting material obtained by the in vitro method made it possible to obtain an industrial yield of blue honeysuckle $(0.67 \mathrm{~kg} / \mathrm{bush})$ already for 4 years after planting and to increase the total yield over the years of research by 3.0 times in comparison with the variant of using when laying plantings with hardwood cuttings and 1.8 times with soft wood cuttings.

\section{Conclusions}

As a result of the conducted studies. a significant influence of various methods of propagation of the Michurinskoe Divo blue honeysuckle variety on the development of the planting material root system was established. The use of seedlings obtained by the in vitro method contributed to a high growth dynamics of crop growth and the rapid entry of plants into commercial fruiting. in comparison with other variants of the experiment. 


\section{References}

1. Association of Blue honeysuckle Producers, URL: http://Haskapru.com (access date 25.03.2021)

2. M.Yu. Akimov. V.V. Bessonov. V.M. Kodentsova. K.I. Eller. O.A. Vrzhesinskaya. N.A. Beketova. O.V. Kosheleva. M.N. Bogachuk. A.D. Malinkin. M.A. Makarenko. L.V. Shevyakova. I.B. Perova. E.V. Rylina. V.N. Makarov. T.V. Zhidekhina. V.A. Koltsov. A.N. Yushkov. A.A. Novotortsev. D.M. Bryksin. N.V. Khromov, Feeding issues 4, 220-232 (2020)

3. M. Kula. M. Majdan. A. Radwańska. A. Nasal. R. Hałasa. D. Głód. A. Matkowski. M. Krauze-Baranowska, Academia Journal of Medicinal Plants 1(8), 141-148 (2013)

4. A.Yu. Ampleeva. T.E. Bocharova. D.M. Bryksin, Biochemical assessment of blue honeysuckle fruits as raw materials for processing, Scientific achievements and innovations in the production. storage and processing of agricultural products: mat. of the int. scientific conf., Michurinsk-naukograd, 242-244 (2011)

5. T.V. Zhidekhina. D.M. Bryksin, Non-traditional agricultural. medicinal and ornamental plants 1 (5), 35-42 (2010)

6. B. Bors, Haskap berry breeding and production; follow up to ADF grant 20060140, Agricultural Development Fund. Saskatchewan Ministry of Agriculture, Grant \#20080042. URL: http:////www.agriculture.gov.sk.ca/apps/adf/ADFAdminReport/ 20080042.pdf (Access date 25.03.2021)

7. D.M. Bryksin. S.A. Kolesnikov. M.I. Kitsur, Fruit and berry growing in Russia 50, 8083 (2017)

8. V.A. Gudkovsky. L.V. Kozhina. A.E. Balakirev. Yu.B. Nazarov. T.V. Zhidekhina, Possibilities of extending the terms of realization of blue honeysuckle berries, The state and prospects of development of blue honeysuckle culture in modern conditions: mat. of int. scientific method. conf. Michurinsk, 180-186 (2009)

9. D.M. Bryksin, Development of methods for storing blue honeysuckle fruits in STEPAC polymer bags, Introduction of non-traditional and rare plants: materials of the VIII International Scientific Conf., Michurinsk-naukograd 1, 111-117 (2008)

10. I.K. Gidzyuk, Blue-fruit garden blue honeysuckle, 162 (Tomsk, Tomsk Univ. Publishing House, 1978)

11. State Register of Selection Achievements Authorized for Use for Production Purposes (1). Plant varieties: Blue honeysuckle, M, 680 (2020). URL: http:// gossortrf.ru/wpontent/uploads/2020/03/FIN_reestr_dop_12_03_2020.pdf.

12. A.E. Solovyova, Scientific basis of propagation of berry crops in Western Siberia: abstract. of diss. of doctor of Agricultural Sciences, 50 (Michurinsk, 2005)

13. D.M. Bryksin, Sweet blue honeysuckle is the pride of Russia, 110 (Chelyabinsk, 2010)

14. J. Sedlák, F. Paprštein, Hort. Sci. (Prague) 34 (4), 129-131 (2007)

15. Program and methodology of variety study of fruit. berry and nut crops, 608 (Orel, VNIISPK, 1999)

16. M.N. Plekhanova. Blue honeysuckle in the garden and nursery, 65 (St. Petersburg, 1998)

17. E.I. Kolbasina. A.D. Pozdnyakov, Medicinal berries, 39-44 (M., Znaniya, 1991)

18. O.S. Rodyukova, Productivity of red currant varieties, Proceedings of the All-Russian Scientific Research Institute of Horticulture n.a. I.V. Michurin: Coll. of Sc. Works, 438-447 (Voronezh, Kvart, 2005) 
19. A.A. Zhuchenko, Adaptive crop production (ecological and genetic bases), 413 (Kishinev, 1990)

20. D.M. Bryksin, Realization of the productivity potential of the newest collection of blue honeysuckle breeding of SSU VNIIR n.a. N.I. Vavilov in the conditions of the Tambov region, Fruit and berry growing in Russia: Collection of scientific works, 76-82 (VSTISP, M., XXIX, 2012) 